\title{
PERANAN UNICEF DALAM MENANGANI \\ CHILD TRAFFICKING DI INDONESIA
}

\section{Nori Oktadewi}

Magister IImu Hubungan Internasional

Universitas Muhammadiyah Yogyakarta

norioktadewi97@gmail.com

\section{Khairiyah}

Magister IImu Hubungan Internasional

Universitas Muhammadiyah Yogyakarta

khairiyah.zolnedi@gmail.com

\begin{abstract}
Child Trafficking is part of child abuse and one of the global issues. United Nation has established organization special for children, the organization is UNICEF (United Nations International Children's Emergency Fund). UNICEF defines a system to protect Children as a component of law, policy, regime and services needed in all the social sectors For Protect the children, Indonesia has ratifications Convention Right of The Children, passed on 20 November 1989, and started to have the force of law on 2 September 1990. For overcome child trafficking in Indonesia UNICEF makes a Program NPAs (National Plan of Action for the Elimination of Child). This research is descriptive research, which is explaining about the role of UNICEF regarding to overcome Child Trafficking especially in Indonesia. This Research aims o know how the role of UNICEF to overcome Child Trafficking of the children In Indonesia and what the factor has influenced child trafficking in Indonesia still high although Indonesia was cooperation with UNICEF .Presented data is secondary data which is collected from various book, article, journals, newspapers and internet related cases. Result of this research show us about child trafficking in Indonesia still high, this matter influenced by External factors like local Government, security Agency, geographical, law institution and society (was influenced by proverty, low information and education, low pay attention by parents).
\end{abstract}


Keyword: UNICEF, Child trafficking, United Nation, NPAs, Global issues

\section{PENDAHULUAN}

Perdagangan anak atau yang biasa disebut dengan child trafficking merupakan salah satu kejahatan yang telah lama berlangsung di seluruh belahan dunia, hal ini menjadi isu krusial didunia international, kasus perdagangan anak adalah salah satu bentuk pelanggaran HAM. Perdagangan anak adalah salah satu bentuk perekrutan perpindahan serta pengiriman orang yang ber- tujuan untuk eksploitasi, dengan cara penipuan, kekerasaan dan pemaksaan, anak-anak dipaksa menjadi pekerja seks, perbudakan serta penjualan organ tubuh. Bisnis perdagangan anak dianggap bisnis yang sangat menguntungkan.

Masalah perdagangan anak (Child Trafficking) sampai saat ini masih belum bisa terselesaikan secara tepat, baik oleh pemerintah di setiap negara, maupun oleh organisasi-organisasi international yang berwenang dalam menangani perdagangan manusia. Child Traffficing berhubungan erat dengan gabungan antarnegara, karena perdangan anak biasanya dilakukan di daerah perbatasan negara dengan modus operasi yang dilakukan adalah pengiriman ke berbagai negara penerima seperti Malaysia dan Singapura. Lemahnya penjagaaan dan keamanan daerah perbatasan menjadi faktor utama perdagangan manusia, sehingga dengan mudah seseorang dapat melakukan transaski perdagangan manusia seperti perdagangan perempuan, anak-anak bahkan lakilaki yang berpendidikan rendah.

Kasus perdagangan banyak terjadi di belahan dunia, terutama di kawasan Asia Tenggara, seperti Indonesia, Thailand, Kamboja dan Vietnam. Kawasan Asia Tenggara dianggap sebagai kawasan yang stategis bagi para pelaku kejahatan lintas batas negara, baik untuk dijual di negara sendiri maupun di luar negeri. Indonesia adalah salah satu negara yang berada di kawasan Asia Tenggara yang terletak sangat strategis dan negara yang merupakan negara maritim karena 2/3 negara Indonesia merupakan lautan, di sebelah barat Indonesia berbatasan dengan Samudera Hindia, sebelah timur berbatasan dengan Papua New Guinea, sebelah utara berbatasan dengan Laut Cina Selatan, Singapura, Malaysia dan Filipina serta sebelah selatan berbatasan dengan Australia, 
sehingga dapat diketahui bahwa Indonesia merupakan sebuah negara yang mempunyai banyak daerah yang langsung berbatatasan dengan negara lain. Sehingga dengan banyaknya perbatasan dengan negara lain, terjadi per- dagangan manusia di Indonesia, terutama perdagangan perempuan dan anakanak, baik dalam negeri maupun di luar negeri (Niko, 2017).

Semakin maraknya kasus perdagngan anak yang terjadi diberapa negara, mengharuskan dunia international memberikan perhatian serius untuk mengatasi masalah ini. Untuk menangani masalah-masalah ini PBB telah membentuk sebuah organisasi yang berwenang dalam mengurusi masalah anak, yaitu UNICEF (United Nations Chilidren's Fund). Dalam menagani perdagangan anak/ Child trafficking di Indonesia, UNICEF membuat program NPAs (National Plan of Action for the Elimination of Chilid Trafficking). Pengimplementasian National Plan of Action for the Elimination of Child Trafficking (NPAs) terwujud dengan adanya pelaksanaan program-program yang berkaitan dalam upaya menangani masalah perdagangan anak di Indonesia. Meskipun UNICEF telah berperan dalam penanganan kasus Child trafficking dengan program NPAs dan UNICEF telah menekan pemerintah Indonesia untuk melakukan Advokasi Anak melalui pembuatan UU khusus perlindungan anak namun kasus child trafficking di Indonesia mengalami peningkatan dan UNICEF mempunyai kendala dalam menangani kasus Child Trafficking. Namun upaya UNICEF dalam menangani kasus Child Trafficking telah dilakukan sejak dulu, namun kasus Child Trafficking di beberapa negara bukan menurun tetapi malah meningkat, begitu hal nya di Indonesia (Ebbe, 2008).

\section{Rumusan Masalah}

Berdasarkan Latar belakang masalah di atas, maka dapat dirumuskan suatu pokok permasalahan yaitu:

"Apa yang menjadi faktor ketidak effektifan UNICEF dalam menangani kasus Child Trafficking di Indonesia?"

\section{Studi Pustaka}

Untuk menjawab pertanyaan Apa yang menjadi faktor ketidak effektifan UNICEF dalam menangani kasus Child Trafficking di Indonesia, maka penulis melakukan review terhadap literature-literatur berikut: 


\section{Berdasarkan buku Child Protection: An Introduction karya} Chriss Beckett, dijelaskan bahwa sebagian besar negara telah memperkenalkan undang-undang maupun aturan hukum untuk melindungi dan mencegah anak- anak maupun generasi muda dari ancaman pihak tertentu yang dapat membahayakan maupun merugikan mereka (Beckett, 2007). Asumsi Chriss Beckett ini didukung oleh gagasan besar dalam buku Understanding International Law yang ditulis oleh Conway W. Henderson di mana pada bagian Human Rights juga turut diterangkan bahwa upaya perlindungan terhadap anak telah dibentuk melalui adanya Konvensi Hak Anak yang telah disahkan pada tanggal 20 November 1989 dan mulai memiliki kekuatan mengikat secara penuh pada tanggal 2 September 1990. (Henderson, 2010).

Konvensi Hak Anak merupakan instrument yang merumuskan prinsip-prinsip universal dan norma hukum mengenai kedudukan anak di mana PBB menyatakan bahwa anakanak berhak atas perawatan dan bantuan khusus serta pengembangan kepribadian secara utuh dan harmonis. Anak juga harus dibesarkan dalam lingkungan kekeluargaan, dalam suasana kebahagiaan, kasih sayang dan pengertian. Konvensi Hak Anak disahkan dengan tujuan untuk memberikan perlindungan terhadap anak, dan menegakkan hak-hak anak di seluruh dunia.

Dilansir dari buku pedoman yang dibentuk oleh UNICEF dalam UNICEF Child Protection Strategy disebutkan bahwa sistem perlindungan anak adalah seperangkat layanan yang dijalankan pemerintah dan dirancang untuk melindungi anak-anak dan generasi muda di bawah umur dan mendorong stabilitas di dalam keluarga.UNICEF mendefinisikan sistem perlindungan anak sebagai suatu komponen hukum, kebijakan, peraturan dan jasa yang dibutuhkan di semua sektor sosial dan kesejahteraan terutama sosial, pendidikan, kesehatan, keamanandan keadilan dalam rangka mendukung pencegahan dan penanganan resiko terkait perlindungan (UNICEF, Protecting the World"s Children: Impact of the Convention on the Rights of the Child in Diverse Legal System, 2007). Pada tingkat pencegahan, tujuan UNICEF yakni mendukung dan memperkuat keluarga untuk mengurangi pengucilan sosialdan mengurangi resiko pemisahan, kekerasan dan eksploitasi anak. 
Selain itu, dikutip dari jurnal ilmiah yang ditulis oleh Muhammad Lutfi Chakim yang berjudulPerlindungan Anak, dipaparkan bahwa di Indonesia, anak dari sisi kehidupan berbangsa dan bernegara dilihat sebagai masa depan bangsa dan generasi penerus cita-cita bangsa. Oleh karena itu, negara berkewajiban memenuhi hak setiap anak atas kelangsungan hidup, tumbuh kembang, partisipasi maupun perlindungan dari tindak kekerasan dan diskriminasi. Selain itu, baik pemerintah, masyarakat, keluarga, dan khususnya orang tua anak berkewajiban dan bertanggung jawab terhadap penyelenggaraan perlindungan anak.Untuk itu pemerintah mengeluarkan dan mengesahkan undang-undang tentang perlindungan anak yaitu UU No. 23 Tahun 2002.

(CHAKIM, 2012)

Selain itu, terkait dengan perlindungan anak, berdasarkan penelitian yang dilakukan oleh Irwanto dari Lembaga Penelitian Universitas Atmajaya Jakarta, ditemukan bahwa tingkat kekerasan terhadap anak mengalami peningkatan setiap tahunnya dengan berbagai kondisi yang berbeda-beda. Kekerasan domestik atau kekerasan yang terjadi di dalam lingkungan keluarga menduduki porsi terbesar dalam kasus kekerasan anak-anak usia 3 - 18 tahun (Irwanto, 1995). Sebanyak 80 persen kekerasan yang menimpa anak-anak dilakukan oleh keluarga mereka, dan 10 persen terjadi di lingkungan pendidikan.Seharusnya keluarga menjadi lembaga sosial pertama dan utama yang memiliki peranan sangat penting dalam memberikan perlindungan terhadap anak.Angka kekerasan ini terus meningkat secara drastis setiap tahunnya sehingga diperlukan perhatian besar dari pemerintah dalam hal upaya penegakan hukum terkait dengan perlindungan anak di Indonesia. Rezim-rezim perlindungan anak di Indonesia harus diimplementasikan secara optimal sehingga dapat dicapai hasil yang memuaskan demi mewujudkan tercapainya hak-hak anak.

Berbeda dengan beberapa literature review di atas, tulisan ini memiliki sudut pandang lain dalam menanggapi permasalahan Child Traffickingdi Indonesia. Di mana tulisan ini lebih menitikberatkan tentang peranan UNICEF dalam mengatasi Child Traffickingdi Indonesia.

\section{Kerangka Teori}

1. Hubungan Internasional Pada umumnya studi Hubungan 
Internasional merupakan suatu pola hubungan atau interaksi antaraktor yang melintasi suatu batas negara. Hubungan internasional juga berkaitan dengan politik, sosial, ekonomi, budaya dan interaksi lainnya di antara state actor dan non state actor. Menurut Mc. Clelland, dalam Perwita, mendefinisikan bahwa Hubungan Internasional sebagai berikut: "Hubungan Internasional sebagai studi tentang interaksi antara jenis-jenis kesatuankesatuan sosial tertentu, termasuk studi tentang keadaan -keadaan relevan yang mengelilingi interaksi" (Charles A. McClelland, 1981).

Menurut Starke dalam bukunya "An Introduction to International Law" juga tidak memberikan batasan yang khusus mengenai pengertian organisasi internasional. Ia hanya membandingkan fungsi, hak, dan kewajiban serta wewenang berbagai organ lembaga internasional dengan negara yang modern. Pada awalnya seperti fungsi suatu negara moderns mempunyai hak, kewajiban, dan kekuasaan yang dimiliki beserta alat perlengkapannya, semua itu diatur oleh hukum nasional yang dinamakan hukum konstitusi negara sehingga dengan demikian organisasi internasional sama halnya dengan alat perlengkapan negara modern yang diatur oleh hukum konstitusi internasional (Starke, 1989).

\section{Organisasi Internasional}

Organisasi internasional adalah organisasi antar negara yang diikat oleh perjanjian untuk menjamin tujuan bersama.

Mengacu pada fungsi (Roles) organisasi internasional menurut Karen Mingst adalah organisasi internasional seperti PBB, Bank Dunia, dan UNICEF dapat memainkan peran kunci di setiap level analisisnya, ada beberapa fungsi Organisasi Internasional menurut tingkat analisisnya. Pertama, di tingkat Sistem Internasional- yaitu Organisasi Internasional mempunyai fungsi untuk berkontribusi bersama dengan UNICEF sebagai salah satu lembaga PBB yang berkonsentrasi dalam meningkatkan kesejahteraan anak dan perlindungan anak dari kekerasan dan pelanggaran hak anak termasuk perdagangan anak yang terjadi di seluruh dunia. UNICEF mempunyai aturan yang harus dimainkan untuk mencapai kesuksesan.UNICEF ada di setiap sudut dunia ini telah diketahui di manapun dan mempunyai pengetahuan track record yang telah diakui kredibilitasnya (Mingst, 1999). 
Menurut Teuku May Rudy dalam bukunya "Administrasi dan Organisasi Internasional" menegaskan bahwa peran Organisasi Internasional adalah sebagai berikut: (Teuku May Rudy)

1. Wadah atau forum untuk menggalang kerja sama serta untuk mengurangi intensitas konflik antar sesama anggota.

2. Sebagai sarana perundingan untuk menghasilkan keputusan bersama yang saling menguntungkan.

3. Dan ada kalanya bertindak sebagai lembaga yang mandiri untuk melaksanakan kegiatan yang diperlukan (antara lain kegiatan sosial kemanusiaan, bantuan untuk pelestarian lingkungan hidup, pemugaran monumen bersejarah, peace keeping, operation dll).

Adapun Hambatan Organisasi

Internasional dalam Menjalankan fungsinya Sebagai berikut:

1. Hambatan Regulasi yang meliputi kerangka, arah kebijakan, dan peraturan

2. Hambatan Institusional seperti tidak adanya badan arbitrasi yang menengahi konflik di antara anggota Organisasi Internasional.
3. Hambatan Lingkungan, yaitu lingkungan internal dan eksternal suatu organisasi internasional serta situasi dan kondisi lingkungan masyarakat internasional.

4. Hambatan Birokrasi adalah struktur organisasi yang ditandai dengan kepatuhan terhadap prosedur standar.

5. Hambatan Politis yang seringkali dihadapi oleh suatu organisasi internasional: Terbatasnya Kedaulatan Setiap Negara anggota organisasi internasional.

6. Hambatan keuangan terdiri dari, terbatasnya waktu, terbatasnya pendanaan, dan terbatasnya sumber daya dalam mengoperasionalkan organisasi internasional guna mencapai tujuan bersama.

Setiap Organisasi Internasional dibentuk untuk menjalankan fungsi fungsi danperan-peran sesuai dengan tujuan pendirian Organisasi Internasional.Adapun fungsi Organisasi Internasional menurut Harold K. Jacobson digolongkan dalam 5 kategori, di antaranya (Jacobson, 1979).

1. Fungsi Informasi

Fungsi ini berkenaan dengan fungsi organisasi sebagai wadah 
informasi.Organisasi internasional mengumpulkan data sekaligus menganalisanya, lalu mengadakan pertukaran data menyebarkan data serta menginformasikan sudut pandangnya atau pendapatnya.

\section{Fungsi Normatif}

Fungsi ini berkaitan erat dengan pembentukan norma-norma atau prinsip-prinsip, baik yang berupa deklarasi ataupun pernyataan-pernyataan yang dapat memengaruhi lingkungan domestik atau dunia. Fungsi ini tidak mengikat instrument-instrumen yang terlibat, tetapi lebih pada suatu pernyataan yang diakui umum.

\section{Fungsi Pembuatan Peraturan}

Fungsi ini berkaitan dengan peranan sebuah organisasi internasional untuk membuat sebuah peraturan baru atau mengupayakan agar peraturan, perjanjian yang telah disepakati dan ditandatangani serta diratifikasi dapat mengikat pihakpihak yang terlibat langsung.

\section{Fungsi Pengawasan}

Fungsi ini yang berhubungan dengan pengawasan atau pengambilan tindakan untuk menjamin penegakan berlakunya sebuah peraturan oleh para aktor internasional.

\section{Fungsi Operasional}

Fungsi ini meliputi pemanfaatan dan pengoperasian segala sumber daya di dalam sebuah organisasi internasional, baik berupa pendanaan, pengoperasian sub organisasi atau juga perkembangan dan pembangunan kekuatan militer.

Klasifikasi organisasi internasional yang terdiri dari organisasi negara maupun organisasi non negara memiliki peran sebagai wadah dalam memecahkan masalahmasalah bersama.UNICEF tergolong sebagai organisasi internasional antarpemerintahan (Inter Govermental Organization) yang sering disingkat menjadi IGO. Anggota-anggotanya adalah pemerintah, atau wakil instansi yang mewakili pemerintahan suatu negara secara resmi. Kegiatanadministrasinya diatur berlandaskan hukum publik (Rudy, 2005).

Dengan menggunakan kedua teori ini, penulis menggunakan teori Hubungan International dan Organisasi Internasional untuk landasan analisa permasalahan dalam fenomena hubungan international. Teori ini adalah teori pengenalan dasar dalam penulisan jurnal ini.

\section{Defenisi Konsepsional}

Dalam pemahaman mengenai masalah yang diteliti, maka perlu untuk dikemukakan makna dari 
konsep-konsep yang dipergunakan. Defenisi konsepsional merupakan defenisi yang menggambarkan konsep dengan menggunakan konsep-konsep lain.

\section{Defenisi Anak}

Menurut Konvensi Perserikatan Bangsa-Bangsa mengenai Hak Anakanak (United Nations Convention on the Rights of the Child 1989), "Seorang anak berarti setiap manusia yang berusia di bawah 18 tahun.Anak adalah manusia yang belum matang, didefinisikan dalam hukum internasional adalah mereka yang berusia di bawah 18 tahun 1 Masa kanak-kanak adalah suatu tahapan dalam siklus kehidupan anak sebelum mereka mendapat peran dan bertanggung jawab penuh sebagai orang dewasa. Masa anak masih memerlukan perhatian dan perlindungan khusus, seiring dengan persiapan menuju pada kehidupan mereka menjadi orang dewasa. Meskipun demikian, setiap kebudayaan memiliki kata yang berbeda untuk berbagai tahapan dalam masa kanak- kanak, dan harapan tentang apa yang dapat dilakukan anak pada masing-masing tahapan.

\section{Perdagangan Anak}

Perdagangan anak merupakan salah satu bentuk tindakan kejahatan yang dapat dilakukan oleh seseorang atau sekelompok orang atau sebuah lembaga terhadap ia belum berusai 18 tahun, maka ia adalah anak termasuk yang masih di dalam kandungan. Perdagangan anak didefinisikan oleh ODCCP (Office for Grug Control and Crime Prevention) sebagai perekrutan, pemindahan, pengiriman, penempatan atau menerima anak-anak di bawah umur untuk tujuan eksploitasi dan itu menggunakan ancaman, kekerasan, ataupun pemaksaan lainnya seperti penculikan, penipuan, kecurangan, penyalahgunaan wewenang maupun posisi penting. Perdagangan anak biasanya bertujuan: eksploitasi untuk pekerjaan, eksploitasi seksual, eksploitasi untuk pekerjaan ilegal perdagangan adopsi, serta penjodohan.

\section{Hipotesa}

Faktor ketidak effektifan UNICEF dalam menangani kasus Child Trafficking di Indonesia, karena:

1. Indonesia masih dipengaruhi faktor internal seperti kurangnya kepedulian pemerintah daerah, Keamanan, letak geogfaris, lembaga hukum dan masyarakat. 


\section{PEMBAHASAN}

\section{a. Sejarah UNICEF di dunia} international dan Indonesia

UNICEF adalah sebuah organisasi international di bawah naungan PBB (Perserikatan Bangsa-bangsa) yang bergerak dalam kesehatan, air, lingkungan, per- lindungan serta pendidikan dan HIV/AID. UNICEF terbentuk Pasca Perang Dunia II, di mana PBB mulai mepromosikan perdamaian dunia. Kekhawatiran PBB dan masayrakat dunia international terhadap anak-anak yang ada di Eropa, sehingga pada tahun 1946, para delegasi untuk PBB menyiapakan dana sementara yang disebut United International Children's Fund, dengan tujuan untuk membantu anak-anak yang ada di dunia, bukan hanya untuk anak-anak yang berada dalam Perang Dunia II.UNICEF mempunyai mandat untuk melindungi jiwa anak-anak dan meningkatkan

pengembangannya.Sidang Umum PBB dengan keputusan pada tanggal 11 Desember 1946 memutuskan berdirinya UNICEF atau United Nations International Children's Emergency Fund (Dana Darurat Anak Internasional PBB).

Sidang Umum PBB mengubah mandat UNICEF untuk menanggapi kebutuhan-kebutuhan yang tidak diungkapkan tetapi sangat mendesak dari sekian banyak anak yang tidak terhitung jumlahnya di negara berkembang.Pada bulan Oktober 1953, Sidang Umum dan tetap PBB. Badan ini disebut the United Nations Children's Fund/ Dana PBB untuk Anak- anak, UNICEF mulai menjangkau negara terbelakang dalam proyek terutama yang dengan cara saling terkait, menyangkut gizi, pelayanan kesehatan primer dan pendidikan dasar bagi ibu dan anak, yang melibatkan sebanyak mungkin anggota masyarakat (May, 2005) UNICEF juga mebuat Konvensi Hak anak, di mana Konvensi Hak Anak disahkan pada tanggal 20 November 1989, dan mulai memiliki kekuatan memaksa pada tanggal 2 September 1990. Sebelum disahkan Konvensi Hak -Hak Anak, Perlindungan dan penegakan Hak-Hak anak, mengalami sejarah yang panjang dengan melalui usaha perumusan draf hak-hak anak yag dilakukan oleh Mrs. Eglantyee Jebb, yakni pendiri Save the Children Fund. Berdasarkan catatan UNICEF, ada beberapa tahap penting dalam sejarah perkembangan hak-hak anak, antara lain adalah (May, Administrasi dan Organisasi Inter- nasional, 2005) Tahun 1923: Hak-Hak anak disetujui oleh Save the Children International Union 
- Tahun 1924: Hak yang disetujui oleh League Nation, karena pada tahun 1924 terjadi kasus pelanggaran dan kekerasan anak pada masa perang Dunia Pertama.

- Tahun 1948: Majelis umum PBB mengesahkan Deklarasi Universitas Hak Assasi Manusia, walaupun hak anak sudah termasuk didalam nya, namun banyak yang berpendapat bahwa kebutuhan khusus anak perlu disusun dalam suatu dokumen secara terpisah.

- Tahun 1959: Majelis PBB mengangkat kembali Deklarasi Hak Anak yang ke dua, sehingga Komisi HAM PBB memulai mengerjakan konsep Konvensi Hak-Hak Anak.

- Tahun 1989: Konsep Hak-Hak Anak disetujui oleh Majelis Umum PBB.

Konvensi Hak Anak merupakan instrument yang merumuskan prinsip-prinsip universal dan norma hukum mengenai kedudukan anak. Konvensi Hak- Hak Anak merupakan hasil dari konsultasi dan pembicaraan negara-negara, lembaga-lembaga PBB dan 50 lebih dari organisasi International.Dan pergerakan ini adalah bukti dari pergerakan global negara di Dunia dengan mengesahkan Konvensi Hak-Hak Anak sebagai bagian hukum nasional negara.

Konvensi Hak Anak tahun 1989 yang disepakati dalam sidang Majelis Umum (General Assembly) PBB ke-44, yang selanjutnya telah dituangkan dalam Resolusi PBB No. 44/25 tanggal 5 Desember 1989 berisi:Penegasan Hak Anak, Perlindungan anak oleh negara, dan Peran serta berbagai pihak (pemerintah, swasta dan masyarakat) dalam menjamin penghormatan terhadap Hak Anak.

Konvensi Hak-Hak Anak terdiri dari 54 pasal yang berdasarkan materi hukumnya yang mengatur mengenai Hak-Hak Anak dan mekanisme implementasi hak anak oleh negara peserta yang meratifikasi Konvensi Hak-Hak Anak, sehingga dapat dikelompokan dalam 4 katagori hak-hak anak, yaitu Hak dalam kelangsungan hidup (survival rights), Hak dalam perlindungan (protection rights), ak untuk tumbuh kembang (Development Rigths) dan Hak berpatisipasi (participation rights). Prioritas UNICEF adalah untuk membuat anak lebih baik. Kerja UNICEF dapat dikelompokkan menjadi lima bidang strategis utama. (Barus, 2010). Kelima bidang ini yaitu kelangsungan 
hidup dan pengembangan anak, pendidikan dasar dan kesetaraan Gender, melindungi anak dari HIV/AIDS, perlindungan anak dan advokasi dan kemitraan untuk anak. UNICEF memberikan kontribusi efektif untuk mengurangi kemiskinan, melalui advokasi dan kemitraan yang menciptakan investasi berkelanjutan, pengembangan kelangsungan hidup dan perlindungan anak.UNICEF membantu Indonesia pertama kali pada 1948.Saat itu terjadi situasi darurat yang memerlukan penanganan cepat akibat kekeringan hebat di Lombok. Kerja resmi antara UNICEF dan pemerintah Indonesia dijalin pertama kali pada 1950. Sejak awal masa kemerdekaan, UNICEF tetap dianggap mitra Indonesia yang berkomitmen untuk memperbaiki hidup anak-anak dan wanita di seluruh nusantara.Prioritas awal UNICEF adalah memberikan pelayanan dan persediaan yang sangat diperlukan untuk memperbaiki kesehatan anak Indonesia dan keluarganya. (Unicef, 2012)

Indonesia meratifikasi konvensi hak anak pada 26 January 1990 dengan keputusan presiden Nomor 36 tahun 1990.UNICEF berkarya di 12 kantor wilayah untuk membantu melaksanakan program di 15 propinsi yang mencakup lebih dari 20 juta orang Indonesia. Bersama dengan mitramitranya UNICEF berhasil membantu mengembangkan dan melobi adopsi Undang -undang Perlindungan Anak 2002. Undangundang ini akan menjadi landasan hukum bagi perlindungan hak anak di Indonesia. Berbagai bentuk dukungan mulai dari adanya dukungan terhadap undang-undang, UNICEF juga membantu dalam bidang pembiayan bagi anak-anak korban eksloitasi seksual komersial yang ingin terlepas dari belenggu keterpurukannya.

Bagi UNICEF operasi besarnya ialah program gizi di Indonesia yang mencapai 100 desa di delapan provinsi (1959). Indonesia yang rejoined ntuk $\mathrm{PBB}$, pada November 1966 setelah keluar dari PBB (1965), oleh menteri Luar Negeri Adam Malik , menandatangani "Surat perjanjian baru mengenai penangan anak di Indonesia", antara UNICEF dan Indonesia. Pada Oktober 1953, setelah Indonesia resmi bergabung dengan UNICEF. Untuk Indonesia salah satunya UNICEF memberikan bantuan tenda-tenda sekolah gratis ke daerah Hiliduho yang terletak di perbukitan yang terletak sangat terpencil, yang mempunyai luas sekitar 221,65 
km2. Di daerah ini juga terdapat perubahan struktur permukaan tanah yang diakibatkan oleh gempa. Akan tetapi untuk di Indonesia UNICEF telah memperlihatkan bentuk kepedulianya terhadap anak dan wanita korban bencana alam yang terjadi di Indonesia.Untuk mengatasi masalah anak yang dihadapi oleh Indonesia, UNICEF juga mempunyai program.Program UNICEF di Indonesia yaitu kesehatan dan gizi, pendidikan dasar untuk semua, perlindungan anak, mengatasi HIV/AIDS dan air dan kebersihan. (UNICEF, www.unicef. org, 2011).

Masih banyak anak-anak Indonesia yang rentan terhadap situasi kekerasan. Kondisi ini menjadi tantangan utama UNICEF dan mitra-mitra lokalnya.Ada beberapa fakta yang cukup memprihatinkan. Diperkirakan sekitar 60 persen anak balita Indonesia tidak memiliki akte kelahiran. Lebih dari 3 juta anak terlibat dalam pekerjaan yang berbahaya. Bahkan, sekitar sepertiga pekerja seks komersil berumur di bawah dari 18 tahun. Sementara 40.000-70.000 anak lainnya telah menjadi korban eksploitasi seksual. Ditambah lagi sekitar 10.000 wanita dan anak-anak diperdagangkan setiap tahunnya. Belum lagi 5.000 anak yang ditahan atau dipenjara di mana 84 persen di antaranya ditempatkan di penjara dewasa. Masalah lain yang tak kalah memprihatinkan adalah pelecehan terhadap anak terutama anak-anak dan wanita yang tinggal di daerah konflik atau daerah bekas bencana. Lebih dari 2.000 anak tidak mempunyai orang tua. Secara psikologis anak-anak itu terganggu sesudah bencana tsunami meluluh lantakkan Aceh dan Sumatra Utara pada 26 Desember 2004.

Bekerja sama dengan pemerintah Indonesia, UNICEF merumuskan kebijakan -ke- bijakan perlindungan anak dan implementasi pengesahan anak secara hukum terutama anak yang tinggal di daerah konflik dan daerah bencana. UNICEF mendukung perkembangan dan implementasi perundangundangan, kebijakan dan program di tingkat nasional maupun daerah seperti misalnya Undang-Undang Perlindungan Anak, Rencana Aksi Nasional terhadap Perdagangan Anak dan kebijakan nasional bagi anak-anak yang terpisah dari keluarganya. Program Perlindungan Anak UNICEF juga bermitra dengan masyarakat madani, sektor swasta, aparat penegak hukum, wakil rakyat, pekerja sosial dan anak-anak dalam upaya menciptakan kerangka 
kerja yang komprehensif. Di samping itu, pencatatan kelahiran untuk semua juga digalakkan untuk mencegah pelanggaran, kekerasan dan eksploitasi terhadap anak-anak. Dalam hal ini, UNICEF mendukung pengembangan mekanisme pelaporan pelecehan terhadap anak-anak di enam kota besar di Indonesia dan penelitian-penelitian di kabupaten di Indonesia.

\section{b. Child Trafficking di Indonesia}

Perdagangan manusia saat ini menjadi perhatian dunia International, karena child trafficking terjadi dari suatu negara ke negara lain, eksploitasi anak dan perempuan terjadi setiap tahunnya, sehingga hal ini harus menjadi perhatian pemerintah maupun masyarakat sendiri. Setiap negara memiliki kewajiban untuk memenuhi hak anak atas azas: non diskriminasi, kepentingan yang terbaik bagi anak, Hak untuk hidup, kelangsungan hidup dan perkembangan, serta penghargaan tentang pendapat seorang anak. Sehingga anak yang diperdagangkan tidak mendapatkan hak-haknya dan tidak bisa menuruti apa yang anak inginkan.

Perdagangan manusia tentu mencari keuntungan, baik untuk pribadi ataupun kedua belah pihak serta hajat hidup orang banyak. Motif utama dari child trafficking adalah ekonomi yang akan berimbas pada kajian hubungan international lainhya. Banyaknya kasus child trafficking terjadi secara transnational karena kemudahan bagi para pelaku untuk dilacak dalam gerak-geriknya. Era globalisasi cukup meberikan kontribusi terhadap perkembangan child trafficking, di mana untuk memobilitas child trafficking dari satu negara kenegara lain sangat mudah dilakukan. Perdagangan anak kadang kala terjadi atas permintaan dan motif bagi pengguna jasa dari tindakan krimininal. Adapun beberapa faktor penyebab terjadinya tindakan child trafficking adalah faktor kemiskinan, kurangnya pendidikan dan Informasi dan kurangnya kepedulian orang tua.Karena banyaknya terjadi perdagangan anak di Indonesia, sehingga pemerintah Indonesia dibantu oleh UNICEF membuat upaya-upaya untuk mengurangi child trafficking di Indonesia, di mana UNICEF dan dunia international menekan Indonesia untuk mengadopsi konvensi Hak anak. Upaya-upaya tersebut adalah:

- Dibuatkannya Undang-Undang yang relevan untuk mem- berikan perlindungan kepada 
korban Trafficking yaitu UU No. 37/1997 tentang Hubungan Luar Negeri. Di mana UU ini dapat melindungi orang Indonesia yang tertaffick di luar negeri.

- Undang-Undang No. 21 tahun 2007, tentang pemberantasan tindak pidana perdagangan orang.

- Undang-Undang No. 23 Tahun 2002 tentang perlindungan anak, termasuk melarang perdagangan anak di mana perlindungan terhadap anak itu sendiri terdapat tujuan dari perlindungan anak sendiri diebut dalam Pasal 3 UU No. 23 Tahun 2002 yang berisi

"Perlindungan anak bertujuan untuk menjamin terpenuhnya hakhak anak agar dapat hidup, tumbuh berkembang, dan berpartisipasi secara optimal sesuai dengan harkat dan martabat kemanusiaan, serta mendapatkan perlindungan kekerasan dan diskriminasi, dmi terwujudnya anak Indonesia yang sejahterah, berkualitas dan berakhlak mulia.

- Adanya RPSA (Rumah Perlindungan Sementara Anak) yang memilki fungsi:

a. Memberikan pelayanan segera bagi anak yang menghadapi tindak kekerasan dan perlakuan salah (Emergency Service)

b. Perlindungan (protection)

c. Pengembalian keberfungsian sosial anak agar dapat melaksankan perannya secara wajar (rehabiltasi)

d. Pemulihan kondisi mental anak akibat tekanan dan trauma.

e. Advokasi

f. Penyatuan kembali nak pada keluarga asli, keluarga pengganti serta lembaga lainya (reunifikasi)

Pengutamaan komitmen pemerintah republik Indonesia dalam penghapusan perdagangan orang tercermin dari keputusan Presiden Republik Indonesia Nomor 88 Tahun 2002, tentang Rencana Aksi Nasional Penghapusan Perdagangan Perempuan dan Anak (RAN-P3A) dan adanya UndangUndang Penghapusan Tindak Pidana Perdagangan Orang (UU PTPPO). Program Legislasi Nasioan; 20052009 menegaskan RUU tindak Pidana Perdagangan Orang berada di urutan 22 dari 55 prioritas RUU yang akan dibahas pada tahun 2005 . Pendikana hukum kepada pelaku (trafficker) digiatkan melalui kapasitas penegak hukum 
serta peningkatan kerja sama dengan pemangku kepentingan yang lain pada pihak penegak hukum negara shabat sehingga kepolisian RI berhasil memproses 23 kasus dari 43 kasus yang terungkap. Dengan upaya- upaya dia atas dapat dilihat bahwa pemerintah Indonesia dan UNICEF serius dalam menangani kasus childtrafficking , meskipun upaya tersebut masib sangat jauh dari apa yang diharapkan. Karena telah diketahui bahwa Indonesia berada pada kawasan Asia Tenggara yang memilki jumlah yang sangat besar dalam prakter perdagangan anak international.Oleh karena itu UNICEF sebagai lembaga atau badan yang menangani masalah perlindungan anak menaruh perhtian yang sangat besar terhadap indpnesia. Saat ini UNICEF membuat program, dalam berbagai isu di Indonesia yaikni baik dalam kesehatan, Pendidikan dasar Untuk semua, Perlindungan Anak, memerangi HIV/AIDS serta air dan kebersihan lingkungan.

Keterlibatan UNICEF dalam membantu pemerintah Indonesia juga terwujud melalui kerja sama yang dijalankan dalam Nasional Plan of Action For the Elemnination of Child Trafficking (NAPs). Pengimplementasian NPAs terwujud dengan adanya program- program yang berkaitan dengan upaya menangani child trafficking yang ada di Indonesia. Dengan dilandasi deklarasi/ konvensi hakhak anak serta panduan yang sistematis darsi konvensi hak anak tahun 1989 UNICEF menjalaknan fungsinya menangani child trafficking di seluruh dunia, di Indonesia UNICEF membuat Konsep yang bertjuan menciptakan sebuah lingkunagn yang memberikan perlindungan kepada anak. Dengan membangun lima komponen yaitu peraturan, budaya, meningkatkan kewaspadaan anak terhadap Child Trafficking, melibtakan anak-anak melalui forum-forum anak untuk menyuarakan bahaya dari Child trafficking, komitmen pemerintah, dan mengkempanyekan masalah perdagangan anak. Dengan harapan child trafficking di Indonesia akan berkurang serta membuka kesadaran masyarakat akan ma- salaah Child Trafficking dan semakin mendorong pemerintah untuk mengurangi child trafficking yang ada di Indonesia.

\section{c. Faktor Penghambat UNICEF dalam menangani Kasus Child Trafficking di Indonesia \\ UNICEF sebagai organisasi} internasional yang bergerak dalam melindungi dan menjamin perlindungan- anak memiliki 
fungsi yang sesuai dengan tujuan pendiriannya.Dalam mencapai misinya, UNICEF telah berhasil menjalankan beberapa fungsi organisasi internasional. Fungsi organisasi internasional yang telah dijalankan oleh UNICEF dalam misinya mengatasi perdagangan anak di Indonesia adalah

\section{Fungsi Informasi}

UNICEF telah menjalankan fungsi ini dengan baik dan benar. UNICEF mewujudkannya dengan berbagai upaya yaitu dengan mengkampanyekan kepada masyarakat internasional tentang bahayanya perdagangan anak. Melalui Program NAPs, UNICEF melakukan kampanye melalui siaran radio, televisi, seminar ataupun berupa kegiatan atau pelatihan khusus yang ditujukan kepada anak-anak dan remaja. Sehingga dengan hal ini diharapkan masyarakat sadar akan bahaya trafficking dan ekploitasi anak.

\section{Fungsi Normatif}

Dalam fungsi ini, UNICEF berhasil membangun sebuah norma atau prinsip yang berupa deklarasi atau pernyataan, yang telah memengaruhi masyarakat internasional. Namun fungsi ini tidak mengikat instrumeninstrumen yang terlibat, tetapi dapat memengaruhi lingkungan domestik. Dalam mewujudkan fungsi ini, UNICEF berupaya untuk melindungi anak-anak dari segala bentuk kekerasan, kekerasan dan eksploitasi.UNICEF melakukan langkah- langkah meliputi pencegahan, bantuan langsung dan penuntutan serta penelitian berbasis bukti. Pendekatan utama yang dilakukan UNICEF adalah untuk mengurangi kerentanan anak-anak di daerah yang ditunjuk untuk menghilangkan segala bentuk perdagangan anak (UNICEF, www. unicef.org, 2006).

\section{Fungsi Pembuatan Peraturan}

Fungsi ini berkaitan dengan peranan sebuah organisasi internasional untuk membuat dan mengupayakan sebuah peraturan yang telah disepakati dan ditandatangani serta diratifisir dapat mengikat pihak-pihak yang terlibat langsung. Dalam mewujudkan fungsi ini, Konvensi Hak Anak menjadi dasar bagi UNICEF untuk melindungi hak-hak anak. Pada tanggal 20 November 1989, Konvensi Hak Anak telah disahkan oleh PBB, dan mulai mempunyai kekuatan memaksa pada tanggal 2 September 1990. Konvensi ini menjelaskan bahwa anak-anak berhak mendapatkan perlindungan dari berbagai pelecehan, 
pengabaian, perdagangan, pekerja anak dan bentuk-bentuk eksploitasi. Sehingga, dalam hal ini UNICEF tidak memiliki wewenang untuk membuat peraturan termasuk dalam proses meratifikasi Konvensi Hak Anak tetapi yang berhak meratifikasi sebuah konvensi adalah pemerintah Indonesia. Indonesia meratifikasi Konvensi Hak Anak pada tanggal 26 January 1990 dengan keputusan Presiden Nomor 36 tahun 1990. Serta pemerintah Indonesia membuatkan UU khusus perlindungan.

\section{Fungsi Pengawasan}

Fungsi ini yang berkaitan dengan pengawasan atau pengam- bilan tindakan untuk menjamin penegakan berlakunya sebuah per- aturan oleh para aktor internasional. Serta pemerintah Indonesia boleh memberikan sanksi terhadap pelaku pelanggaran sesuai dengan undangundang perlindungan anak yang ada di Indonesia. Meskipun dalam menjalankan fungsi Operasional UNICEF belum berhasil menjalankan fungsi ini dengan baik meskipun UNICEF telah mampu mengalokasikan dana dengan baik, namun UNICEF memiliki keterbatasan dalam menggunakan sumber daya dan technicalassistance lainnya dalam misi menanggulangi masalah perdagangan anak di Indonesia. Dalam menjalankan misinya mengatasi perdagangan anak di Indonesia UNICEF telah membentuk proyek atau programprogram kerja. Namun dalam praktiknya UNICEF belum sepenuhnya berhasil dalam mengatasi perdagangan anak di Indonesia.Hal ini disebabkan oleh adanya faktor-faktor yang menimbulkan terjadinya perdagangan anak yang sulit untuk diberantas sampai saat ini.

Meskipun UNICEF telah menjalankan beberapa fungsinya denga baik, namun dalam menangani kasus childtrafficking di Indonesia, UNICEF memiliki hambatan dalam menjalakan perannya.Adapun faktor penghambat UNICEF dalam upaya menurunkan angka childtraffickinhg di Indonesia adalah adanya faktor Internal Di mana faktor Internal yang berasal dari ruang lingkup, seperti:

\section{Pemerintah Daerah}

Pemerintah daerah masih kurang tegas dan masih banyak pemerintah daerah yang belum membuat Undang-undang perlindungan anak meskipun pemerintah pusat telah lama meratifikasi konvensi hak anak. 
2. Aparat keamanan

Kurangnya tindaka aparat keamanan dalam menanggulangi child trafficking. Karena aparat keamanan lebih fokus kepada isu-isu yang terkait dengan korupsi, narkoba dan isu-isu lainnya.

3. Letak Geografis.

Telah diketahui Indonesia berada di wilayah yang strategis dan Indonesia memiliki banyak perbatasan dengan negaranegara lain sehingga hal inilah yang menyebabkan sulitnya UNICEF melakukan perannya dalam mengurangi angka childtrafficking di Indonesia.

4. Lembaga Hukum

Indonesia masih disibukkan dengan kasus-kasus tentang korupsi dan kasus internal lainnya.sehingga masalah yang dihadapi anak masih belum diprioritaskan dan diabaikan oleh hukum di Indonesia.

5. Masyarakat.

Dalam hal ini faktor masyarakat sangat memengaruhi masih banyaknya perdagangan anak di Indonesia. Faktor-faktor masyarakat dapat berupa

a. Kemiskinan (Permasalahan Ekonomi)
Semenjak terjadinya krisis ekonomi pada tahun 1997 di Indonesia, hal ini memberikan dampak yang buruk terhadap kehidupan masyarakat, karena perekonomian semakin sulit, semakin banyak rakyat yang tidak mampu mebiayai keluarganya, khususnya anaknya mulai dari biaya pendidikan, hingga biaya kehidupan sehari-hari. Sehingga himpitan ekonomi membuat keluarga khususnya orang tua semakin mudah terbujuk rayuan oleh agen atau perlaku perdagangan anak dengan iming-iming serta janji palsu akan pekerjaan yang mampu mebuat hidup akan lebih baik lagi dengan gaji yang besar. Ketidakjelasan pekerjaan membuat orang menjadi pasrah dalam menerima pekerjaan untuk dipekerjakan sebagai apa saja dan hal ini yang membuat para pelaku menargetkan anak menjadi korban.

b. Kurangnya Pendidikan dan Informasi.

Pendidikan yang memadai tentunya akan sangat membantu masyarakat agar tidak terjebak dalam kasus perdagangan anak. Kekurangan pengetahuan akan informasi mengenai ChildTrafficking membuat orangorang lebih mudah terjebak untuk menjadi korban ChildTrafficking khususnya di 
pedesaan dan terkadang tanpa disadari pelakuk perdagangan anak tidak menyadari bahwa telah melanggar hukum. Para korban perdagangan biasanya susah untuk mencati bantuan dinegara di mana dia diperdagangkan karena mereka tidak memilki kemampuan untuk menggunakan khususnya bahasa di negara tersebut. Di sisi lain orang tua yang berada di Indonesia, daerah terpencil masih banyak yang mempunyai- pendidikan yang rendah dan bekerja sebagai petani, ataupun pekerja domestik, sehingga hal inilah yang membuat kurangnya informasi yang mereka dapatkan tentang bahaya childtrafficking, meskipun UNICEF telah melakukan kempanye dan penyuluhan melalui forum-forum tentang bahaya childtrafficking.

c. Kurangnya kepedulian orang tua.

Di Indonesia banyak sekali orang tua tidak membuat akte kelahiran terhadap anaknya dengan berbagai alasan. Orang tanpa tanda pengenal yang memadai sangat mudah dijakdikan korban child trafficking, karena tidak terdokumentasi dalam pemerintahan. Sehingga pelaku dapat melakukan aksinya tanpa khawatir serta identitas korban tidak mudah terlacak. Sehingga faktor eksternal inilah yang membuat pemerintah Indonesia dan UNICEF dalam menangani permasalahan child trafficking di Indonesia menjadi tidak maksimal.

\section{KESIMPULAN}

Child Trafficking adalah isu global yang sulit untuk diselesaikan baik oleh pemerintah negara-negara yang ada di dunia maupun organisasi yang khusus menangani masalah child trafficking, seperti halnya UNICEF yang berada di bahwah naungan PBB yang khusus menangani hak-hak anak. Child trafficking di Indonesia terjadi karena beberapa faktor yaitu kemiskinan, kurangnya pendidikan dan informasi serta penegakan hukum di Indonesia yang masih lemah walaupun pemerintah Indonesia telah bekerja sama dengan UNICEF dalam menangani kasus child trafficking serta pemeritah Indonesia telah didorong oleh UNICEF untuk meratifikasi konvensi hak anak dan membuat undang-undang perlindungan hak anak seperti yang tercantum dalam UU Nomor 23 tahun 2003, UU Nomor 21 Tahun 2007 serta adanya RPSA dan UNICEF telah membuat program NAPs untuk mengurangi angka trafficking di Indonesia, namun kasus Child trafficking di Indonesia tetap saja tinggi karena 
Indonesia masih di pengaruhi faktor eksternal yang berada dalam ruang lingkup pemerintah daerah, aparat keamanan, letak geografis, lembaga hukum dan masyarakat sendiri yang dipengaruhi oleh faktor kemiskinan, kurangnya informasi dan pendidikan serta kurangnya kepedulian orang tua.

Saran dari penulis adalah pemerintah- Indonesia harus memberikan ketegasan dalam memberikan izin untuk pergi keluar negeri terutam jika ada yang ingin memalsukan dokumen, menigkatkan ekonomi dan membuat program dan inisaiatif di luar negeri untuk membantu mengintegritaskan, meintegrasi dan pemulihan para korban, serta para aparat, lembaga hukum juga konsisten dalam menangani kasus perdagangan anak dengan memprioritaskan penanganan dan meberikan hukuman bagi terdakwa. Di sisi lain hendaknya memperkuat keterampilan korban dan para keluarga untuk melawan child trafficking lewat pendidikan, organisasi dan advokasi secara indidvidu dan kolektif.

\section{Bibliography}

Kekerasan Terhadap Anak Timbulkan Gangguan Mental. (2003). http:// www. nu. or.id/ a, public-m, dinamic-s , detailids,1- id,137-lang, id-c, warta-t, Kekerasan + Terhadap + Anak + Timbulkan + Gangguan+ Mental-.phpx.

Barus, P. (2010). Tinjauan Pustaka Mengenai UNICEF. http:// repository.usu.ac.id , http:// repository.usu.ac.id/ bitstream/ 123456789 /17244/ 3/ Chapter $\% 20$ II.pdf.

Beckett, C. (2007). Child Protection : An Introduction. India:

SAGE Publications.

CHAKIM, M. L. (2012).

Pe r li n d u n a n A n a k. http://w w w. lut f icha $\mathrm{k}$ im . com/2012/01/perlindungananak.html.

Charles A. McClelland, H. A. (1981).

Ilmu Hubungan Internasional:

Teori dan Sistem. Cv. Rajwali.

Ebbe, O. N. (2008). Global trafficking in women and children. Boca Raton: CRC Press Taylor \& Francis Group. Henderson, C. W. (2010). Understanding International Law. United Kingdom: John Wiley and Sons .

Indonesia, u. (n.d.). www.unicef. org. Retrieved from http:// www.unicef.org/indonesia/id/ activities.html 
Indonesia, U. (n.d.). www.unicef. org. Retrieved from https:// www.unicef.org/indonesia/id/ media_6260.html

Irwanto. (1995). Pekerja anak di tiga kota besar : Jakarta, Surabaya, Medan. Jakarta : Unicef : Atma Jaya.

Jacobson, H. K. (1979). Networks of Interdependence: International Organization and The GlobalPolitical System. New York: Alfred A. Knope.

May, R. T. (2005) . Administrasi dan Organisasi Internasional. Jakarta: Refika Aditama.

May, R. T. (2005) . Administrasi dan Organisasi Internasional. Jakarta: Refika Aditama.

Mingst, K. (1999). Essentials of International Relations. New York: W. W. Norton and Company.

Niko, N. (2017, Juni). FENOMENA TRAFFICKING IN PERSON DI WILAYAH PERBATASAN KALIMANTAN BARAT.
Rudy, T. M. (2005). Administrasi dan Organisasi Internasional. Bandung: Refika Aditama.

Starke, J. (1989). Pengantar Hukum Internasional. Jakarta: Sinar Grafika.

UNICEF. (2007). Protecting the World"s Children: Impact of the Convention on the Rights of the Child in Diverse Legal System. New York: Cambridge University Press.

UNICEF. (2006). www.unicef. org. Retrieved 01 31, 2018, from https://www.unicef. org/publications/files/Child_ Protection _ Information _ Sheets.pdf

UNICEF. (2011), www.unicef. org. Retrieved from https:// www.unicef.org/indonesia/id/ activities.html

Unicef. (2012). www.unicef.org. Retrieved Juni 4, 2018, from Kerja Sama UNICEF dengan Indonesia: http://www.unicef. org/indonesia/id/media_6260. html 